Joanna Gorzelana

Uniwersytet Zielonogórski

\title{
Biblizmy we współczesnej literaturze popularnej na przykładzie „Kolekcji Kryminałów” Joanny Chmielewskiej
}

Korzenie cywilizacji europejskiej sięgają starożytnej kultury basenu Morza Śródziemnego. Na płaszczyźnie językowej nawiązania te uwidaczniają się przez obecność mitologizmów i biblizmów, które stały się zasadniczym składnikiem utartej frazeologii nowożytnych języków europejskich. Za Janem Godyniem [1995: 7] przyjmuję, że biblizmami są wyrazy oraz utrwalone, stałe związki wyrazowe, które pochodzą z języka polskich przekładów Biblii lub powstały pod wpływem treści Biblii. Kształt polskich biblizmów uzależniony jest od języka pierwszych tłumaczeń Pisma Świętego, a szczególnie od translacji ks. Jakuba Wujka, gdyż korzystano z niej w Kościele katolickim przez ponad 350 lat, co sprzyjało petryfikacji struktur biblijnych XVI-wiecznej polszczyzny [zob. Bieńkowska 2002: 14-23; Koziara 2001: 29-32]. Formy te funkcjonują nie tylko w tekstach artystycznych, ale także w języku potocznym i w polskiej literaturze popularnej ostatniego półwiecza, chociaż tłumaczenie Wujkowe nie jest już stosowane w polskiej liturgii kościelnej.

Celem pracy jest przedstawienie biblizmów i ich form zmodyfikowanych, które występują w „Kolekcji Kryminałów” Joanny Chmielewskiej. Kolekcja obejmuje 25 tomów powieści wydawanych w latach 1964-2007. Materiał sprawia wrażenie reprezentatywnego dla gatunku, choć przyjmuję, że w zestawieniu z innymi powieściami kryminalnymi, które były publikowane w tym samym czasie, mogą pojawić się różnice w stosowaniu biblizmów. Wyekscerpowałam z powyższych powieści biblizmy, zwracając uwagę na ich aspekt formalny i funkcjonalny. Liczba użytych form wskazuje na stosunkowo słaby stopień nasycenia biblizmami tego typu literatury.

Najpierw omówię biblijne określenia, które zawierają zasymilowane semityzmy leksykalno-pojęciowe, czyli wyrazy zaczerpnięte z języków hebraj- 
skiego i aramejskiego. W powieściach Chmielewskiej są to rzeczowniki gehenna $\mathrm{w}$ zwrocie przeżyć gehennę [24: 308]' 'przeżyć, przejść bolesne, ciężkie cierpienia psychiczne lub fizyczne, męczarnie'² i manna w wyrażeniu manna z nieba [10: 190] 'cud, nieoczekiwany dar; zyski' [Bąba, Liberek 2001: 427]. Semityzmem jest także leksem amen, który w powieściach Chmielewskiej pojawia się w trzech typach konstrukcji: po pierwsze - na amen w znaczeniu 'całkowicie, zupełnie' [Bąba, Liberek 2001: 20], po drugie - jako zapewnienie prawdziwości w porównaniu jak amen $w$ pacierzu. Dodam, że formułą potwierdzającą prawdziwość wypowiedzi są też zastosowane w języku bohaterów frazy: Jak Bóg na niebie [13: 58], Bóg mi świadkiem [10: 209]. Ostatni, trzeci typ użycia leksemu amen spotkać można w zwrocie: daj Boże, amen [16: 289], który wygłaszają bohaterowie powieści, wyrażając swe życzenia. Oto przykładowy materiał:

Ta straszna myśl, że ich nie zna zatruje mu duszę na śmierć, na amen. [2: 92] ${ }^{3}$

A oni się wyprą jak amen w pacierzu. [24: 331]

Panicz Pamiętowski po to właśnie jeździł, żeby ich [żołnierzy polskich - J.G.] odnaleźć, bo nie bardzo wie, gdzie są, ale że są, rzecz jest, co daj Boże, amen. [16: 285].

Do języka oryginalnego nawiązują także zapelatywizowane na gruncie

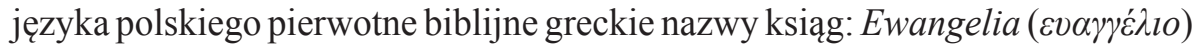
i Apokalipsa ( $\alpha \pi \circ \kappa \alpha ́ \lambda v \psi \eta)$ [Koziara 2009: 24]. Pierwsza tworzy zwrot: wierzyć $w$ coś jak w ewangelie 'wierzyć w coś bardzo, niezachwianie, całkowicie' w takim znaczeniu wypowiada te słowa bohaterka jednej z powieści [16: 341], uwydatniając tym samym ogrom zawiedzionego zaufania. $Z$ kolei do ostatniej księgi Biblii nawiązuje przymiotnik apokaliptyczny 'dotyczący apokalipsy, wspominany, opisywany w Apokalipsie; wieszczący koniec świata, budzący grozę, przerażający'. Chmielewska stosuje go w wyrażeniach potwór apokaliptyczny i wizja apokaliptyczna w następujących kontekstach:

Ryczący potwór apokaliptyczny znalazł się tuż za mną i wtedy wreszcie we wstecznym lusterku dostrzegłam znaki kierowcy. [7: 120]

1 W kwadratowych nawiasach podano numer pozycji w „Kolekcji Kryminałów” i stronę, na której wystąpił omawiany biblizm.

2 Znaczenie biblizmów podaję za Godyniem [1995], jeśli inaczej - zaznaczono.

3 Wszystkie wyróżnienia w cytowanych przykładach są moje - J.G. 
Apokaliptyczna wizja, wbrew spodziewaniom wywarła skutek odwrotny do zamierzonego, łysa ziemia okazała się niestrawna. [6: 23]

Zastosowanie biblizmu konotującego grozę w opisie trywialnych sytuacji wywołuje efekt humorystyczny.

Inną stosunkowo łatwą do zidentyfikowania grupą biblizmów są staroi nowotestamentowe nazwy własne (antroponimy i toponimy) obecne w języku polskim. Zupełnie zleksykalizowane we współczesnej polszczyźnie jest biblijne imię Cham [Długosz-Kurczabowa 1990: 29-30]. Rzeczownik ten w wyniku przesunięcia semantycznego od XVIII wieku zaczyna przyjmować znaczenie 'człowiek ordynarny, grubiański, nieokrzesany', i obecnie jest to podstawowe znaczenie tego leksemu ${ }^{4}$. Biblizm w powieściach związanych z przestępstwem ma stosunkowo dużą frekwencję (23 użycia), łączy się z epitetami, tworząc wyrażenie: cham niemyty [2: 283] i cham skończony [6: 125]. Tworzy też zwroty pchać się na chama [9: 290], upierać się na chama [19: 325], załatwić na chama [12: 264] - wszystkie w znaczeniu 'niegrzecznie, bezczelnie, nie zważając na nic'. Biblijne imię Cham jest też podstawą derywacyjną dla rzeczownika pospolitego cham i przymiotnika chamski, który w powieściach Chmielewskiej określa rzeczowniki prymityw [19: 276] i świństwo [19: 278]. Powstał od niego przysłówek po chamsku [6: 127] i rzeczownik abstrakcyjny chamstwo [25: 45].

Inne wyrażenie derywowane od imienia bohatera biblijnego to hiobowa wieść 'wiadomość zła, tragiczna, przerażająca; o nieszczęściu'. Konteksty użycia tego biblizmu w powieściach wskazują na powagę sytuacji, do której się odnoszą:

Wkroczyli z hiobowa wieścia na ustach i natychmiast poświęcili się jakimś swoim sprawom, pogrążając nas w coraz głębszym oszołomieniu. [8: 292]

Przedostała się bez trudu do pokoju, w którym państwo spożywali posiłek i przyniosła im wieść hiobową. [20: 61]

W jednym użyciu zmodyfikowano ten frazeologizm, stosując szyk przestawny - wieść hiobowa ${ }^{5}$. Modyfikacji uległo również wyrażenie niewierny

4 Współczesne słowniki podają też znaczenie archaiczne: ,[... ] w języku warstw uprzywilejowanych: pogardliwie o człowieku należącym do niższej klasy, głównie o chłopie” [Dubisz, red. 2003: 394].

5 Modyfikacja składniowa frazeologizmów biblijnych dotyczy najczęściej szyku [zob. Kucała 1997: 52]. 
Tomasz, które zredukowano do samego imienia, poprzedzonego zaimkiem nieokreślonym taki. Jest to przykład modyfikacji wymieniającej, najczęstszej wśród modyfikacji frazeologicznych [zob. Bąba 1989: 184]:

[...] ale ja osobiście nie wierzę, żeby oni posiadali tylko jedną sztukę broni palnej. Taki Tomasz jestem. [18: 198]

Kontekst jednoznacznie wskazuje na utrwalony w polszczyźnie biblizm stosowany w odniesieniu do 'osoby nieufnej, sceptycznie nastawionej, chcącej wszystko sprawdzić' [zob. Gorzelana 2011].

W powieściach Chmielewskiej obecny jest też antroponim Samarytanin, derywowany od toponimu Samaria, który pod wpływem przypowieści Jezusa [Pismo Święte... 1980: Łk 10,30-35] przyjmuje znaczenie 'człowiek miłosierny, litościwy, pielęgnujący chorych’ [Długosz-Kurczabowa 1990: 61-62]. Tak jest np. w powieści Złota mucha, w której rzeczownik określony jest epitetem dobry [24: 175]. W wyrażeniach samarytańska pomoc i samarytański odruch, wskazujących na działanie związane z troską o bliźniego, obecny jest też przymiotnik derywowany od tego rzeczownika:

Ustawił sobie te nogi całkowicie, bez mojego udziału, ja zaś wystąpiłam tylko w charakterze samarytańskiej pomocy. [11: 214]

Beata w samarytańskim odruchu, a może w chęci ujrzenia jego oblicza, ponownie skoczyła do kuchni, zmoczyła pod kranem papierowe ścierki, podała mu. [9: 237]

Wśród biblizmów pochodzących od toponimów dużą frekwencję (17 użyć) ma w analizowanych powieściach wyrażenie sodoma i gomora, które występuje też dwukrotnie w postacie skróconej - sodoma, jako forma charakterystyczna dla idiolektu bohaterki [16: 182, 372] ${ }^{6}$. Wyrażenie to przyjmuje znaczenie 'wielkie zamieszanie, rozgardiasz, awantura', łączy się z czasownikiem podkreślającym bądź początek procesu: zaczęła się [1: 34], zrobiła się [2: 19], zapanowała [17: 184], wybuchta [18: 282], bądź jego trwanie: jest [25: 138], panuje [13: 32], dzieje się [3: 309], np.

Od tego momentu zaczęła się sodoma i gomora. [1: 34]

6 Bohaterka stosująca skróconą formę jest osobą niewykształconą, która pracuje jako pomoc domowa. 
Ci, którzy wpadli, chwycili go w objęcia, on strzelał dalej w różnych kierunkach, wrzaski się wzmogły, razem wziąwszy zrobiła się sodoma i gomora, większość osób rzuciła się pod stoły i zdaje się, że tylko ja jedna trwałam nieruchomo na swoim miejscu. [2: 19]

Obecność tego wyrażenia w powieściach kryminalnych jest uzasadniona tematycznie, a jego frekwencja świadczy o powszechnym przyswojeniu biblizmu w polszczyźnie?

Kolejnymi frazeologizmami zawierającymi odniesienie do biblijnego toponimu są wyrażenia egipskie ciemności 'wielka, gęsta, nieprzenikniona ciemność' i plagi egipskie 'zwykle w 1p. o czymś bardzo dokuczliwym, nieznośnym, uciążliwym'. Genetycznie odnoszą się one do okoliczności wyjścia narodu wybranego z niewoli egipskiej. W powieściach wskazują na sytuacje zagrożenia i silnego napięcia emocjonalnego:

Bezustannie jakieś podejrzane typy pętają się koło nas w egipskich ciemnościach. [7: 164]

Ona czy nie ona rąbnęła Krzewca, jeśli nie ona, zrazi świadka, sam sobie rzuci kłody pod nogi, ma być uprzejmy, do plagi egipskiej! [22: 70]

To drugie wyrażenie w badanej literaturze pojawia się tylko raz, w funkcji wykrzyknienia.

Również nazwa miasta Jerycho jest bazą derywacyjną dwóch biblizmów. Pierwszym z nich jest wyrażenie mury Jerycha definiowane jako 'przeszkody dające się łatwo obalić, łatwo rozpadające się w proch'. Użyte zostało przez powieściopisarkę w kontekstach sygnalizujących przeciwne znaczenie, gdyż wskazuje na podejmowanie wielkiego wysiłku: rozwalać mury Jerycha [11: 248], walka z murami Jerycha [9: 65], walenie w mury Jerycha [25: 156], np.

[...] zaraz potem stwierdził, że młodzieniec mówi do głuchego głosem zdolnym rozwalać mury Jerycha. [11: 248]

Przeraziłam się jeszcze bardziej, pewno że musiało jej się tam coś stać, oberwała rezerwuar czy co?... ale to byłby jeden rumor, a nie długa walka z murami Jerycha. [9: 65]

7 Częstość występowania biblizmu potwierdza wyszukiwarka PELCRA [2014]. 
[...] bo grała. Nie osobiście, miała te urządzenia określane jako muzyczne, moim zdaniem, do walenia murów Jerycha lepsze niż trąby, i przekazywała nimi dźwięki straszliwe. [25: 156]

Do nazwy miasta Jerycho nawiązuje też wyrażenie traba jerychońska, które powieściopisarka wyzyskała w dwóch znaczeniach: 'głuptas' i 'silny, głośny dźwięk’. Można tu więc mówić o pewnej homonimii frazeologizmu. Wyrażenie trąba jerychońska wzmaga siłę ekspresji, zarówno gdy pełni funkcję wyzwiska, jak i kiedy mówi o sile dźwięku, np.

Trafił akurat na chwilę, kiedy Justynka głosem jak trąba jerychońska przedarła się przez potok słów ciotki. [23: 423]

Trąby jesteście - powiedział Janusz niecierpliwie - Jerychońskie. [3: 270]

W drugim przykładzie doszło do rozerwania związku frazeologicznego, co mogło wpłynąć na zwiększenie ekspresji wypowiedzi bohatera [Miodońska-Brookes, Kulawik, Tatara 1978: 311].

Ostatnim biblizmem motywowanym nazwą własną, w powieściach Chmielewskiej występującym tylko jeden raz, jest wyrażenie wieża Babel 'zamieszanie, zamęt, nieład, pomieszanie języków; wielojęzyczne zbiorowisko ludzi'. Biblizm zmodyfikowano poprzez dodanie epitetu całkowita, który podkreśla domniemany chaos:

Pomyślałam sobie, że zaraz przejdzie na angielski dla wszystkich bardziej zrozumiały i wtedy będzie już całkowita wieża Babel. [10: 259]

Wśród pozostałych biblizmów wykorzystanych przez Chmielewską w powieściach kryminalnych spotyka się też inne utrwalone połączenia wyrazowe. Do niezmienionych przez powieściopisarkę wyrażeń zaliczymy dwa określenia ludzi: aniot stróż 'przen. opiekun, obrońca, nieodstępny towarzysz' i kozioł ofiarny 'o kimś, na kogo zrzuca się niesłusznie całą odpowiedzialność za coś, co jest negatywnie określane'. Obie formy zostały użyte jeden raz [23: 111 i 11: 212], w narracji, nie zaś w wypowiedziach bohaterów.

Stosunkowo często spotykamy natomiast synonimiczne określenia wskazujące na bardzo długi, nieskończony czas: do sądnego dnia [np. 7: 39, 14: 94] i do końca świata [11: 201] $]^{8}$; pojawia się także forma do skończenia świata

8 Według Godynia [1995: 86] do końca świata znaczy 'nie wiadomo jak długo, zawsze, bardzo długo', do sądnego dnia 'bardzo długo, w nieskończoność, beznadziejnie'. 
[13: 276]. Powyższe wyrażenia (bez przyimka) mogą także pełnić funkcję przenośnego określenia poruszenia i przerażenia ${ }^{9}$. Wyrażenie sądny dzieńn ${ }^{10}$ łączy się z czasownikami wskazującymi na początek procesu: rozpocząt się [13: 29], zrobit się [16: 160], nastat [13: 219]. Z kolei biblizm koniec świata występuje najczęściej z innymi określeniami nieszczęść, np.

Dostaliśmy dubla z tyłu i rozpoczął się sądny dzień. Personel ruszył do szturmu na nieszczęsną salę konferencyjną, bo nikt oczywiście nie wierzył krzykom Wiesi. [13: 29]

Koniec świata, dno i mogiła. [2: 39]

Ostatnia doba zaznaczyła się czymś w rodzaju końca świata, trzęsienia ziemi, dantejskiego piekła razem wziętych. [3: 98]

Wśród innych biblizmów spotykamy wyrażenie chleb powszedni 'rzecz codzienna, zwykła, nic nadzwyczajnego'. Wyrażenie to w powieściach Chmielewskiej odnosi się najczęściej do patologicznego zachowania bohatera, przykładowo do zbrodniczego zamiaru [3: 80] lub szaleństwa [1: 195]. Może wskazywać też na informację neutralną, taką jak wypowiedź dotycząca wizyty [15: 117] czy tajnikow totalizatora, np.

Progenitura pracowników pętała się po terenie w dużej ilości, dla większości tych dzieci konie stanowily ulubione zwierzątka domowe, a tajniki totalizatora chleb powszedni. [17: 81]

Przecież cię uczciwie uprzedzałam, że dla mnie szaleństwa to jest chleb powszedni. [1: 195].

Wyrażenie to obecne jest zarówno w wypowiedziach bohaterów, jak i w opisach wszechwiedzącego narratora.

Bez modyfikacji pojawia się w wypowiedzi bohaterki zwrot: pilnować kogoś, czegoś jak oka w głowie, który uplastycznia wypowiedź, gdyż jego

9 Według Godynia [1995: 86] koniec świata to 'emocjonalny okrzyk wyrażający zdumienie, zgorszenie, przerażenie’. Jednak po fragmencie: ,[...] fraza nawiązuje znaczeniem do apokaliptycznych obrazów końca świata" [Godyń 1995: 86], leksykograf zamieszcza odnośnik do wyrażenia sądny dzień 'zamieszanie, popłoch, rozgardiasz, awantura' [Godyń 1995: 86 i 141].

10 Przyjmujemy, że jest to bohemizm [zob. Kucała 1973: 124]. 
znaczenie w powieści to 'strzec szczególnie gorliwie, troskliwie' [19: 344]. Antropomorficzny charakter ma wyrażenie od stóp do głów, oznaczające całego człowieka:

[...] przepełniony ciekawością od stóp do głów. [13: 229]

[...] od stóp do głów przepełniało mnóstwo myśli. [1: 196].

Biblizm odnosił się tu do człowieka, przede wszystkim w wymiarze psychicznym.

Modyfikacjom uległ natomiast inny biblizm zawierający nazwę anatomiczną: mieć olej $w$ głowie ${ }^{11}$. W różnych jego aktualizacjach dochodzi, po pierwsze, do wymiany rzeczownika głowa na łeb. Zmiana ta służy upotocznieniu, a przez to uwiarygodnieniu języka bohaterów. Po drugie, biblizm jest rozwijany o jednostki miary, np. bodaj odrobina oleju we tbie [11: 262], jakieś resztki oleju w głowie [6: 288], trochę oleju w głowie [22: 56], cień oleju w głowie [10: 52], dość oleju w głowie [5: 157].

Kolejnym wyrażeniem potocznym pochodzenia biblijnego w analizowanej kolekcji jest wyrażenie kamień obrazy 'powód przyczyna obrazy, obrażania się, zgorszenia'. W jednym użyciu doszło do gry znaczeń: znaczenia dosłownego i przenośnego, gdyż przedmiotem, który stał się przyczyną utraty honoru i śmierci bohatera, był diament - drogocenny kamień:

Zakładamy dalej, że dziewczyna wyjechała z diamentem [...]. Arabella [...] musiałaby zgłupieć doszczętnie, żeby kręcić powróz na własną szyję. Przyznać, że doprowadziła do samobójstwa męża, ukrywając kamień obrazy? [21: 80]

Takie wyzyskanie znaczenia dosłownego i przenośnego jest wyjątkowe wśród biblizmów stosowanych przez Chmielewską. Występuje natomiast łączenie biblizmów także z innymi frazeologizmami, co wzmacnia plastyczność obrazu, jak w poniższych przykładach:

Przerwałam panu Tadeuszowi, który chwilowo wpuszczał mnie w maliny, w dodatku krętymi ścieżkami. [12: 30]

Daj Boże, Amen! Wyjdę im na prowadzenie, jak amen w pacierzu. [19: 385]

11 Godyń [1995: 114] jako podstawę biblizmu podaje Prz 21,20. 
Uprzedzam cię, że jeśli cię zamkną za fałszywe zeznania, to ja palcem nie kiwnę. Umywam ręce. [10: 55]

W pierwszym przykładzie zastosowano dwa eufemistyczne określenia odnoszące się do okłamywania (wpuszczać w maliny) i nieuczciwego życia (kręte ścieżki) ${ }^{12}$. Na zupełną bierność bohatera wskazują w trzecim przykładzie dwa zwroty: umywać ręce 'zrzucić z siebie odpowiedzialność, odżegnywać się od czegoś' i palcem nie kiwnąć 'nie zdobyć się na najmniejszy wysiłek, nic nie zrobić w jakiejś sprawie, nie pomóc'.

Plastycznej frazy kamień na kamieniu nie zostanie 'zwykle o miastach, budynkach: zburzone, zniszczone, całkowicie, do fundamentów' użyto w znaczeniu, które wskazuje na nadmierną aktywność bohaterki przejawiającą się w porządkach domowych. Biblizm sugeruje, że mieszkanie zostanie zupełnie zniszczone:

Przyleci ze Szwecji jeszcze szybciej niż Małga z Francji i jak się złapią za te porządki wspólnymi siłami, kamień na kamieniu tu nie zostanie. [9: 131]

Frazeologizm został rozbudowany o zaimek (tu), który ma wskazać na miejsce przyszłego spustoszenia ${ }^{13}$. Zastosowana hiperbolizacja wprowadza nastrój żartobliwy.

O realnym zagrożeniu można mówić natomiast w opisie sytuacji, w której pojawia się biblizm znaki na niebie i ziemi wskazują 'zachodzą jakieś wydarzenia, zjawiska, które mogą być interpretowane jako zapowiedź czegoś, co się wydarzy, nastąpi':

[...] wszystkie znaki na niebie i ziemi wskazywały nadciąganie burzy, połączonej nawet, być może z gradobiciem, kwestie agrarne pchały się natrętnie na pierwszy plan. [8: 208]

Można tu zauważyć defrazeologizację biblizmu, gdyż związek odnosi się do nadciągającej burzy, której symptomy były widoczne w powietrzu i na ziemi.

12 Wyrażenie kręte ścieżki 'manowce, postępowanie niezgodne z powszechnie przyjętymi zasadami moralnymi i etycznymi' traktować można jako eufemizm [por. Dąbrowska 1996: 33-39].

13 Stanisław Koziara [2009: 98] podaje właśnie rozszerzenie - nie zostanie tu kamień na kamieniu - jako przykład nieuzasadnionej filologicznie modyfikacji (w tłumaczeniu jubileuszowym Biblii), przez dodanie komponentu do struktury utrwalonej. 
Pisząc o oburzeniu bohaterów, autorka trzykrotnie użyła biblizmu woła coś o pomstę do nieba 'coś jest w okropnym stanie, wywołującym zgrozę i oburzenie; rażąca niesprawiedliwość'. Związek ten odnosił się do postępowania „miastowego głupka, tych rządów” i „ukrywania zalet konia”:

To co teraz te rządy robią, wota o pomstę do nieba, straszna hołota się wszędzie pcha, lepiej mieć rodzinę. [16: 37]

Miastowego głupka osobiście nie znała, ale słyszała o nim, bo echo jego wołajacych o pomstę do nieba poczynań rozeszło się szeroko. [18: 21]

Ukrywanie zalet i możliwości dobrego konia, jego zdaniem, wolało o pomstę do nieba. [16: 229]

Każde zdanie zawierające biblizm opisywało osoby zachowujące się źle, które były poza zasięgiem ludzkiej sprawiedliwości.

Wśród plastycznych obrazów wskazujących na sytuacje, gdy 'kogoś ogarnie ogromny strach, przerażenie', wyzyskany został często (25 razy) biblizm wtosy się komuś jeżą/stają dęba ${ }^{14}$. Powieściopisarka wykorzystuje różne formy, przykładowo: włos na głowie dęba staje [25: 265]. W tym związku pierwszy rzeczownik w formie syngularnej staje się synekdochą, przez co nabiera większej ekspresji. Autorka często stosuje czasownik w czasie przeszłym, zarówno w wypowiedziach bohaterów, jak i w narracji, np.

A co powiedziała, to wtos na glowie dęba staje. [15: 175]

Włosy stanęty mu dęba na głowie, przed oczami zamajaczyła straszliwa wizja personalnej w postaci uskrzydlonej harpii. [3: 26]

Jest również formuła z bezokolicznikiem poprzedzającym czasownik fazowy zaczynać:

[...] włosy zaczynaty mi stawać dęba na głowie. [2: 294]

Wszechwiedzący narrator wprowadza dwukrotnie czasownik w trybie przypuszczającym: stanęlyby, np.

14 Frazeologizmy te traktuję jako jednostki wariantywne [zob. Godyń 1995: 168]. 
Gdybym wówczas wiedziała, w jakich okolicznościach będę zmuszona się nim posłużyć, włosy stanętyby mi dęba na głowie i kto wie, czy nie rzuciłabym się $\mathrm{w}$ fale oceanu. [2: 131]

Powyższy biblizm przyjmuje także formę włos się jeży. W tym wariancie przeważa użycie rzeczownika w liczbie pojedynczej ${ }^{15}$, ale obecne jest też użycie formy pluralnej: włosy się jeża [8: 145]. Czasownik przyjmuje też formę dokonaną przedrostkową zjeżyć [np. 8: 300; 10: 100] i niedokonaną jeży [np. 4: 288; 17: 83]. Kontaminację omawianych zwrotów zawiera zdanie:

[...] z włosami zjeżonymi dęba na głowie, z sercem w gardle, bez tchu, usiłowała za wszelką cenę opanować sytuację. [2: 89]

Połączenie kontaminacji włosy zjeżone dęba na głowie z wyliczeniem innych oznak fizjologicznych wzmaga wymowę obrazu przerażenia bohaterki.

Podobne źródło biblijne (Hi 4,14-15) jest podstawą synonimicznego biblizmu: strach/groza podnosi/jeży włosy na głowie ${ }^{16}$. W związku z tym, że biblizmy ulegają wielu modyfikacjom, a w słownikach często brakuje informacji o biblijnym pochodzeniu frazeologizmu [zob. Dziamska-Lenart 2007: 205-213; Fliciński 2007: 215-218], za podstawowe formy przyjmujemy te notowane przez słownik Godynia ${ }^{17}$. Powyższy frazeologizm przyjmuje w powieściach kryminalnych różne formy, pojawiają się w nim modyfikacje, oto przykłady:

Wspomnienie poprzednio oglądanych bałaganów podniosło mi włosy na głowie. [19: 319]

Nikt by tu żadnej prawdy nie zeznał, a łgarstwo połączone ze stosownym naciskiem z zewnątrz, dałoby rezultat, od którego włos się podnosi na głowie. [18: 118$]$

15 Na 10 użyć 8 jest w liczbie pojedynczej.

16 '[...] kogoś ogarnia przerażenie' [Godyń 1995: 167].

17 Rozpatrując modyfikacje tego biblizmu, można jednak przyjąć, że podstawą dwóch ostatnich frazeologizmów jest fraza zanotowana przez Stanisława Skorupkę: ,[...] włosy podnoszą się, powstają (na głowie), od czego, z czego (ze strachu, ze zgryzoty, z przerażenia) 'o czymś okropnym, budzącym grozęe”, która nie wymaga wskazania na sprawcę. Przy takim założeniu w podanych przykładach nie byłoby redukcji. Dodajmy, że badacz notuje też frazę, którą przyjmujemy za Godyniem jako podstawową formę biblizmu: coś, strach (groza, przerażenie) jeży, podnosi włosy na głowie [zob. Skorupka 1974: 586-588]. 
Włosy pod peruką podniosty mi się lekko i coś mnie zaczęło dławić. [4: 83]

W pierwszym przykładzie zastosowano modyfikację wymieniającą, wprowadzając rzeczownik wspomnienie w funkcji synonimu rzeczownika strach. W drugim użyciu frazeologizm ulega modyfikacji rozszerzającej [zob. Bąba 1989: 64], gdyż czasownik łączący się w biblizmie z rzeczownikiem w mianowniku (strach podnosi włosy) tworzy tu nowe połączenie z rzeczownikiem w dopełniaczu (od którego podnoszą się włosy). Podobnie zmianom uległ biblizm w ostatnim z powyższych przykładów. Tu zmieniono komponent rzeczownikowy, określając lokalizację włosów na głowie $\rightarrow$ pod peruką. Jest to przykład modyfikacji wymieniającej. Ponadto zmienia się łączliwość czasownika. W tym zdaniu redukcji uległ sprawca działania (strach/groza podnosi włosy na głowie $\rightarrow$ włosy podniosty mi się).

Łącznie w cyklu Chmielewskiej użyto 31 razy formy oznaczające strach i przerażenie. Duża frekwencja tych frazeologizmów (włosy stają dęba, włosy się jeża, włos się podnosi na głowie) uzasadniona jest tematyką powieści kryminalnych, opisujących przestępstwa, które budzą powszechnie trwogę.

Zachowanie wyrażające rozpacz opisuje zwrot rwać włosy z głowy. Wśród użyć spotykamy formę w trybie przypuszczającym - rwałby [4: 13], wskazującą na wewnętrzny stan bohatera, z trudem powstrzymującego się przed ujawnieniem emocji. W jednym użyciu biblizm uległ modyfikacji skracającej, przyjmując postać rwać włosy. Forma ta jest stosowana także w odniesieniu do ludzi zrozpaczonych. Oto wybrane konteksty:

[...] kierownik pracowni tupał nogami i rwał włosy z głowy w zakładzie introligatorskim, gdzie oprawiano plansze na sztywno. [3: 98]

Miałam przed sobą człowieka w skrajnej rozpaczy, widać było, jak stara się opanować, chociaż najchętniej rwałyby włos z głowy i tłukł nią o ścianę. [4: 13]

Chłopak w drugą stronę się obrócił i włosy rwat, a teraz pary z gęby nie puści, bo na nim by się skupiło, boskiego konia z ręki puścił. [18: 10]

W polskiej kulturze pod wpływem Biblii ukształtował się synonimiczny zwrot rozdzierać szaty nad czymś / nad kimś, będący synonimem treści 'ubolewać nad czymś, rozpaczać, lamentować'. Wykorzystany został tylko jeden raz w opisie reakcji na stłuczenie się drogiej chińskiej porcelany [16:394]. 
Podobne znaczenie, obrazujące 'ciężką sytuację, zmartwienie, kłopot', wyraża dwukrotnie użyty biblizm płacz i zgrzytanie zębów. Oprócz wersji podstawowej [4: 214] występuje też forma zmodyfikowana:

I też się boi - podjął Waldemar. - Ogólny strach i zgrzytanie zębów. [17: 204]

Przez wymianę rzeczownika płacz na rzeczownik strach wskazuje się dodatkowo na uczucia towarzyszące bohaterom. Wprowadzona modyfikacja jest więc uzasadniona.

Również określenie przestrzeni może wskazywać na zagrożenie, np. wyrażenie istna jaskinia zbójców 'siedlisko zła, przestrachu, zbrodni'. W powieści biblizm przyjmuje formę bez przymiotnika istna, który potwierdzałby wiarygodność znaczenia [2: 295]. Dodam przy tym, że niektórzy badacze podają ten frazeologizm w formie jaskinia zbójców [Skorupka 1974: 304]. Stanisław Koziara [2001: 75-77] zwraca uwagę na późne utrwalenie konstrukcji w polszczyźnie ogólnej.

W powieściach kryminalnych częściej spotyka się określenia wskazujące na to, co nieprzyjemne, niż sformułowania wzbudzające pozytywne emocje. Określeniem przestrzeni, w której człowiek jest szczęśliwy, jest wyrażenie ziemia obiecana, czyli 'miejsce najbardziej pożądane; kraj szczęśliwości i bogactwa'. Człowiek pragnie dotrzeć do tej przestrzeni, gdyż wierzy, że tam będzie bezpieczny i radosny.

Do Taorminy, tylko do Taorminy, tylko tam, do najpiękniejszego miejsca na świecie!... Myśl o ziemi obiecanej wypchnęła mi z głowy wszystkie inne. [2: 235]

Dla bohaterki wymarzoną krainą jest włoska miejscowość Taormina. Także wyrażenie przyimkowe $w$ raju jest biblizmem obecnym w polszczyźnie w znaczeniu 'w miejscu pięknym, uroczym, mającym sprzyjające warunki do życia, wypoczynku, przyjemnego spędzenia czasu'. Biblizm ten bywa drugim członem porównania z łącznikiem jak [7: 5] lub niczym [16: 309]. Na miejsce piękne, gdzie panuje szczęście, wskazują przenośne zwroty sugerujące przekraczanie granicy raju: przybyć do raju [7: 20], wkraczać do raju [11: 291], wstepować do raju [18: 28].

Rzeczownik raj dwukrotnie występuje jednak w kontekstach kwestionujących jego biblijne znaczenie:

W gruncie rzeczy wiedziałam, że ten raj będzie wybrakowany. [11: 291] 
Istny raj! Nic z tego, nie dla mnie raje, na razie jestem skazana na katorgę umysłową. [10: 55]

W pierwszym przykładzie podważono wartość owego miejsca, opatrując rzeczownik raj epitetem wybrakowany. W drugim zastrzeżenia co do wartości raju budzi połączenie w bliskim sąsiedztwie wykrzyknika istny raj z zaprzeczeniem (nie dla mnie raje), w którym rzeczownik użyty w liczbie mnogiej podkreśla niedostępność jakiegokolwiek raju.

W podobnym znaczeniu, jako określenie czegoś nie do zdobycia, dwukrotnie pojawia się biblizm 'kraj, ziemia, kraina bardzo urodzajna, obfitująca we wszystkie bogactwa' wyrażony frazeologizmem kraina mlekiem i miodem płynaca. Został on zmodyfikowany i umieszczony w kontekstach podważających jego znaczenie:

Polska wieś nie płynęła mlekiem i miodem do tego stopnia, żeby chłopak $\mathrm{z}$ wielodzietnej rodziny wzdrygał się ją porzucić. [20: 186]

[...] może jeszcze Związek Radziecki, bo ten pas [z bursztynem - J.G.] do nich sięga, a oprócz tego mają kopany, ale u nas lepiej, moglibyśmy płynąć mlekiem i miodem, i co? chała denna. [24: 86]

W pierwszym użyciu zastosowano zaprzeczenie czasownika płynąć i wymianie uległ główny komponent - rzeczownik kraina na rzeczownik wieś (opatrzony epitetem polska). Frazeologizm ten został użyty w funkcji okolicznika miary bogactwa. Użyty w zaprzeczeniu wskazywał w sposób zwielokrotniony na biedę, tym wyraźniej, że biblijne asocjacje mogły dodatkowo sugerować opuszczenie przez Boga.

W drugim przykładzie zredukowano biblizm o rzeczownik kraina, a w zamian wprowadzono podmiot konotowany pierwszoosobową formą czasownika. Funkcji podmiotu nie pełni synonim rzeczownika kraina, lecz osoba. Można tu więc mówić o innowacji rozszerzającej, gdyż zmienia się łączliwość komponentów frazeologizmu. Zastosowanie formy czasownika w trybie warunkowym i ekspresywnego wyrażenia w bezpośrednim sąsiedztwie wskazuje na irytację z powodu niemożności życia z wykorzystaniem bogactw.

Interesującym modyfikacjom uległy biblizmy, które w powieściach kryminalnych przybrały formę wołanie kota na puszczy i nie samym łóżkiem człowiek żyje. Oto konteksty: 
Wizyta pułkownika z jednej strony podtrzymywała mnie nieco na duchu, ale z drugiej napełniła obawami, że wszystko, co mówię jest wołaniem kota na puszczy. [2: 324]

Nie samym łóżkiem człowiek żyje. Zakochała się w nim porządnie. [21: 10]

W pierwszym przykładzie konstrukcja wskazuje na biblizm głos wołającego na puszczy' ${ }^{18}$ gdyż ma znaczenie 'rady, polecenia, prośby itp. bezskuteczne, nie znajdujące posłuchu, oddźwięku u kogoś'. Wprowadzenie rzeczownika kot wydaje się bezzasadne, nawet w dłuższym kontekście tekstowym. Inaczej jest w drugim przykładzie, w którym występuje modyfikacja wymieniająca. Do utrwalonej frazy w miejsca słowa chleb wprowadzono rzeczownik łóżko. Zmiana wskazywać może na sytuacje erotyczne, w jakich znajdowali się bohaterowie powieści; przyjmujemy więc, że jest uzasadniona. Rzeczownik tóżko wskazuje na przedmiot symbolizujący miłość erotyczną, określony jako element niewystarczający do szczęśliwej egzystencji osoby zakochanej.

Modyfikowanie utrwalonych frazeologizmów w analizowanych powieściach związane jest najczęściej z wprowadzaniem dodatkowych znaczeń i można je uzasadnić kontekstowo.

$* * *$

Przedstawiając formy i funkcję wybranych biblizmów w powieściach kryminalnych, pragnęłam zwrócić uwagę na funkcjonowanie tych związków we współczesnej polszczyźnie. Ich obecność w literaturze przeznaczonej dla przeciętnego czytelnika świadczy o realnym istnieniu tych struktur w języku [zob. Gozdecka 1992: 79; Chlebda 1998: 17]. Biblizmy występują zarówno na płaszczyźnie narracji, jak i w zróżnicowanych stylistycznie wypowiedziach bohaterów. Służą uplastycznieniu wypowiedzi, wprowadzają nastrój powagi lub efekty humorystyczne. W związku z tematyką powieści przeważają w nich biblizmy wskazujące na nieprzyjemne osoby i sytuacje. Częste są więc użycia rzeczownika cham i jego derywatów oraz frazeologizmów wskazujących na zamieszanie, takich jak: sądny dzień, koniec świata, sodoma i gomora. Stosunkowo wiele jest form zmodyfikowanych. Spotykamy zarówno skrócenia (np. włosy rwać z głowy $\rightarrow$ włosy rwać), jak i rozwinięcia biblizmów (np. mieć olej w głowie $\rightarrow$ mieć trochę oleju w głowie), a także modyfikacje wymieniające (np. niewierny

18 Frazeologizm ten uległ w polszczyźnie przede wszystkim modyfikacji w związku ze zmianą znaczenia leksemu puszcza [Bąba 1984: 235-238]. 
Tomasz $\rightarrow$ taki Tomasz). Modyfikacje frazeologiczne wynikają z potocznego stylu języka powieści, gdyż w badanym materiale dotyczą nie tylko biblizmów.

\section{Bibliografia}

\section{Źródla $^{19}$}

1. Chmielewska Joanna (2010), Klin, Kobra, Warszawa. (wyd. 1 - 1964)

2. Chmielewska Joanna (2010), Całe zdanie nieboszczyka, Kobra, Warszawa. (wyd. 1 - 1972)

3. Chmielewska Joanna (2010), Lesio, Kobra, Warszawa. (wyd. 1 - 1973)

4. Chmielewska Joanna (2010), Romans wszechczasów, Kobra, Warszawa. (wyd. 1 1975)

5. Chmielewska Joanna (2010), Wszystko czerwone, Kobra, Warszawa. (wyd. 11974)

6. Chmielewska Joanna (2010), Dzikie białko, Kobra, Warszawa. (wyd. 1 - 1990)

7. Chmielewska Joanna (2010), Boczne drogi, Kobra, Warszawa. (wyd. 1 - 1973)

8. Chmielewska Joanna (2010), Studnie przodków, Kobra, Warszawa. (wyd. 1 - 1979)

9. Chmielewska Joanna (2010), Kocie worki, Kobra, Warszawa. (wyd. 1 - 2004)

10. Chmielewska Joanna (210), Krokodyl z Kraju Karoliny, Kobra, Warszawa. (wyd. 1 - 1969)

11. Chmielewska Joanna (2010), Zbieg okoliczności, Kobra, Warszawa. (wyd. 1 - 1993)

12. Chmielewska Joanna, Rzeź bezkręgowców, Kobra, Warszawa. (wyd. 1 - 2007)

13. Chmielewska Joanna (2010), Wszyscy jesteśmy podejrzani, Kobra, Warszawa. (wyd. 1 - 1966)

14. Chmielewska Joanna, Depozyt, Kobra, Warszawa. (wyd. 1 - 1999)

15. Chmielewska Joanna (2010), Drugi wątek, Kobra, Warszawa. (wyd. 1 - 1993)

16. Chmielewska Joanna (2010), Najstarsza prawnuczka, Kobra, Warszawa. (wyd. 1 - 1999)

17. Chmielewska Joanna (2010), Wyścigi, Kobra, Warszawa. (wyd. 1 - 1992)

18. Chmielewska Joanna (2010), Florencja córka Diabła, Kobra, Warszawa. (wyd. 1 1993)

19. Chmielewska Joanna (2010), Szajka bez końca, Kobra, Warszawa. (wyd. 1 - 1989)

20. Chmielewska Joanna (2010), Wielki diament, t. 1, Kobra, Warszawa. (wyd. 1 1996)

21. Chmielewska Joanna (2010), Wielki diament, t. 2, Kobra, Warszawa. (wyd. 1-1996)

22. Chmielewska Joanna (2010), Zapalniczka, Kobra, Warszawa. (wyd. 1 - 2007)

19 Numeracja powieści jest taka jak w analizowanej serii wydawniczej. 
23. Chmielewska Joanna (2010), (Nie)boszczyk mąż, Kobra, Warszawa. (wyd. 1 - 2002)

24. Chmielewska Joanna (2010), Złota mucha, Kobra, Warszawa. (wyd. 1 - 1998)

25. Chmielewska Joanna (2010), Babski motyw, Kobra, Warszawa. (wyd. 1 - 2003)

\section{Literatura}

Bąba Stanisław (1984), Modyfikacja zwrotu ,głos wołajacego na puszczy”, „Język Polski", z. 3, s. 235-238.

Bąba Stanisław (1989), Innowacje frazeologiczne współczesnej polszczyzny, Wydawnictwo Naukowe UAM, Poznań.

Bąba Stanisław, Liberek Jarosław (2001), Słownik frazeologiczny współczesnej polszczyzny, PWN, Warszawa.

Bieńkowska Danuta (2002), Polski styl biblijny, Archidiecezjalne Wydawnictwo Łódzkie, Łódź.

Chlebda Wojciech (1998), Biblizmy języka rosyjskiego. Koncepcje opisu leksykograficznego, w: Biblia w literaturze i folklorze narodów słowiańskich, red. Ryszard Łużny, Danuta Piwowarska, Universitas, Kraków, s. 15-33.

Dąbrowska Anna (1996), W adamowym stroju chodzić krętymi drogami. O eufemizmach wywodzacych się z języka religijnego, „Poradnik Językowy”, z. 10, s. 33-39.

Długosz-Kurczabowa Krystyna (1990), Apelatywizacja biblijnych nazw własnych w języku polskim, „Prace Onomastyczne”, nr 33.

Dubisz Stanisław, red. (2003) Uniwersalny stownik języka polskiego, t. 1: A-G, PWN, Warszawa.

Dziamska-Lenart Gabriela (2007), Frazeologizmy biblijne w nowych stownikach frazeologicznych, w: Język religijny dawniej i dziś. Materiaty z konferencji Poznań 24-26 kwietnia 2006, red. Paweł Bortkiewicz, Stanisław Mikołajczak i Małgorzata Rybka, Wydawnictwo „Poznańskie Studia Polonistyczne”, Poznań, s. 205-213.

Fliciński Piotr (2007), Z życia wybranych frazeologizmów biblijnych we współczesnej polszczyźnie, w: Język religijny dawniej i dziś. Materiaty z konferencji Poznań 24-26 kwietnia 2006, red. Paweł Bortkiewicz, Stanisław Mikołajczak i Małgorzata Rybka, Wydawnictwo „Poznańskie Studia Polonistyczne”, Poznań, s. 214-228.

Godyń Jan (1995), Od Adama i Ewy zaczynać. Mały słownik biblizmów języka polskiego, Towarzystwo Miłośników Języka Polskiego, Spółka Wydawniczo-Księgarska, Warszawa.

Gorzelana Joanna (2011), Czy ,niewierny Tomasz” jest wyrażeniem recesywnym?, „Język Polski”, z. 4, s. 305-309.

Gozdecka Ewa (1992), Frazeologia Biblii i jej funkcjonowanie we współczesnym tekście literackim, „Przegląd Rusycystyczny”, z. 3-4, s. 73-79.

Koziara Stanisław (2001), Frazeologia biblijna $w$ języku polskim, Wydawnictwo Naukowe AP, Kraków. 
Koziara Stanisław (2009), Tradycyjne biblizmy a nowe polskie przekłady Pisma Świętego (ujęcie filologiczno-normatywne), Wydawnictwo Naukowe Uniwersytetu Pedagogicznego, Kraków.

Kucała Marian (1973), Bohemizmy frazeologiczne w staropolszczyźnie, „Język Polski”, z. 2-3, s. 118-132.

Kucała Marian (1997), Modyfikacje frazeologii biblijnej, „Roczniki Humanistyczne”, z. 1, s. 51-58.

Miodońska-Brookes Ewa, Kulawik Adam, Tatara Marian (1978), Zarys poetyki, PWN, Warszawa.

PELCRA (2014), http://nkjp.uni.lodz.pl/index_adv.jsp, [dostęp: 1 września 2014].

Pismo Święte Starego i Nowego Testamentu w przekładzie z języków oryginalnych (1980), oprac. zespół z inicjatywy Benedyktów Tynieckich, wyd. 3 popr., Pallotinum, Poznań.

Skorupka Stanisław (1974), Słownik frazeologiczny języka polskiego, t. 1-2, wyd. 2, Wiedza Powszechna, Warszawa.

Joanna Gorzelana

\section{Biblisms in contemporary popular literature exampled in Joanna Chmielewska's detective novels}

The aim of the work is to highlight the vitality and functional diversity of biblisms in contemporary 'low' literature imitating everyday language. This article presents the results of the use dozens of lexical units. Sometimes biblisms are modified- most often they are mentioning modifications (eg. Man cannot live by bed alone $\leftarrow$ Man cannot live by bread alone). Less frequently we meet shortening modifications (eg. pluck hair $\leftarrow$ pluck the hair out) and developing ones(have some remains of oil in the head $\leftarrow$ have oil in the head). These modifications can often be justified contextually. Biblisms used in crime novels usually emphasize the seriousness of the situation and they can also introduce an element of humor.

KEYwORDs: biblism; phraseological modification; popular literature; detective novel.

dr Joanna Gorzelana - Instytut Filologii Polskiej Uniwersytetu Zielonogórskiego; zainteresowania naukowe: stylistyka tekstów artystycznych polskiego oświecenia, związki języka Biblii z polszczyzną dawną i współczesną, a także kultura i język Górali Czadeckich z Bukowiny. 